Framing the Conversation:

Social Studies Education and the Neoconservative Agenda

John Kornfeld, Ph.D.

Professor of Education

Sonoma State University

Address correspondence to: John Kornfeld School of Education Sonoma State University 1801 East Cotati Ave. Rohnert Park, CA 94928 email: john.kornfeld@sonoma.edu tel: (707) 664-4208

fax: (707) 664-2483 
Framing the Conversation:

Social Studies Education and the Neoconservative Agenda

You've got to hand it to the Neocons: They really know how to out-flank the Left. For years—decades, really—many of us have been calling for educational reform, pointing out the shortcomings of public schooling for its anti-democratic structures and policies, irrelevant and sometimes racist curriculum, and myriad other faults. And social studies teachers and curriculum developers have borne the brunt of much of our criticism. Only a few years ago, I myself decried the "moribund state of social studies" education, arguing that "for most students, social studies is a boring, meaningless subject, usually about dead white males who have little or no relationship to their lives" (Kornfeld and Goodman 1998, 306). Now the Neoconservatives have come along and said much the same thing about social studies education in this country. In Where Did Social Studies Go Wrong? (WDSSGW), funded and published in 2003 by the Fordham Foundation, editors Lemming and Ellington $(2003,1)$ declare, "The only possible interpretation of the state of social studies education at the turn of the $21^{\text {st }}$ century is that the field is moribund."

But here's how they have outflanked us: Their call for reform might at first sound like ours, but they are actually advocating very different kinds of changes. In fact, the reasons they cite for the field's demise include many of the reforms-which they claim "dominate" the social studies field—for which the Left, over the years, has most strongly advocated: "such politicized and superficial topics as peace studies, the environment, gender equity issues, multiculturalism, and social and economic justice" (Leming and Ellington 2003, ii). 
These assertions are baffling to those of us who have promoted such reforms. How can they call these issues superficial? And since when have they dominated social studies education? If they have, I certainly haven't noticed it. True, we have championed these causes over the years, and we've actually made some inroads in schools and classrooms; but overall, our impact has been far less profound than we would like. And now the authors of WDSSGW want to wipe out even the small gains we've made? Many on the Left would probably even settle for the anachronistic Perennialist canon that our calls for reform sought to eliminate, instead of the xenophobic jingoism that the Fordham Foundation advocates replacing it with in this book.

The book's condemnation of social studies education puts the Left in a difficult position. On the one hand, we want to continue to critique the shortcomings of Eurocentric, textbook-driven, teacher-lectured, drill-and-kill social studies education that takes place in too many classrooms across the country; on the other hand, the criticism in WDSSGW compels us to defend social studies teachers against this attack from the Right. Many of us have responded in the same way to No Child Left Behind. For years, we've been saying that schools have been failing our students and need to change; but now that NCLB threatens to dismantle schools entirely and hand them over to private interests (Kohn 2004), we're all scrambling to defend the schools. No matter how much we criticized them, we never intended for public schools to be destroyed. As Apple (1996, xv) writes,

Many of us have quite ambivalent feelings about the place called school. All of us who care deeply about what is and is not taught, and about who is and is not empowered to deal with these issues, have a contradictory relationship to these institutions. We want to criticize them rigorously 
and yet in this very criticism lies a commitment, a hope, that they can be made more vital, more personally meaningful and socially critical. If ever there was a love/hate relationship, this is it. This speaks directly to the situation many people in critical educational studies face today.... The New Right is very powerful now. It has had the odd effect of simultaneously interrupting the progressive critique of schooling while leading many of us to defend an institution many of whose practices were and are open to severe criticism.

How did we get to this state of affairs? How did the Right manage to co-opt our reformist agenda and then twist it into the dangerous and destructive educational plan being advocated (and, in the case of No Child Left Behind, being implemented) nationwide? Where Did Social Studies Go Wrong? serves as a perfect illustration of the Neocons' tactics. This article will examine the nature and method of their attack in WDSSGW, which involves the clever and subtle use of language to mischaracterize the Left as powerful, dangerous, and anti-patriotic, and it will suggest ways to respond to these attacks and perhaps counteract their impact.

\section{The Neoconservative Plan of Attack}

The use of language in Where Did Social Studies Go Wrong? is the key to understanding its plan of attack. Let's look at just a few of the words and phrases used to describe the Left sprinkled throughout the book:

- the intellectual elite (Leming 2003, 138)

- progressives and social studies gurus (Rochester 2003, 12, 24)

- cultural relativists (Burack 2003, 54) 
- ignorant activists (Leming 2003, 124) who promote an activist agenda (Ellington and Eaton 2003, 75)

- ideologues who comprise a powerful confluence of institutional forces (Burack 2003, 47)

- radical leftist multiculturalists (Ellington and Eaton 2003, 88)

- too powerful (Finn 2003, II)

- too entrenched in their university posts and their command positions in state education departments (Finn 2003, II)

- anti-patriotic (Rochester 2003, 25, 40)

- a threat to liberty (Leming and Ellington 2003, vi)

You can't dismiss these labels and accusations as simple name-calling. Neocons have used them many times before, in a variety of contexts, and each evokes unflattering and even scary images that are emblazoned, some more than others, on the citizenry's collective consciousness. What, for example, do people picture when they read about the "intellectual elite" and "social studies gurus"? Such labels conjure up images of a cabal of hippie/Commie eggheads who seek to hold hostage our children and college students with "progressive groupthink" (Rochester 2003, 19: note the 1950s Soviet-speak) that is out of touch with mainstream America. In a word (a dirty word in the minds of the Right), the Left is comprised of "progressives."

In the field of education, the term "progressive" serves as Neoconservative code for all that is wrong with today's schools. To them, progressive implies soft thinking, "anti merit, anti-rigor, anti-basics, anti-discipline" (Rochester 2003, 14-15), a dumbing down of the curriculum that Rochester $(2003,14)$ calls "the Oprahization of American education." It consists of touchy-feely student-centered feel-good activities, as opposed to research-driven content-rich teacher-directed instruction (Schug 2004); it "promote[s] 
social constructivism without emphasizing content knowledge" (Frazee and Ayers 2003, 120), conveying little in the way of hard facts to students. As a result of this approach, "children simply don't know enough about history, civics, and geography" (Frazee and Ayers 2003, 120). Worse still, the fuzzy progressive thinking of those radical leftist multiculturalists begets "cultural relativism," which characterizes the defective judgment of postmodern effete intellectual apologists for cultures whose perspectives run counter to the American Way, whose views "are at odds with the views held by a vast majority of Americans" (Rochester 2003, 15).

A few years ago, such accusations would have engendered little concern among the intellectuals who, thanks to academic freedom, felt safe in their ivory towers. We could simply have written and discussed among ourselves how the notion of relativism, as Harding (1987) points out, is disturbing only to those in power whose worldview is being challenged. That is what members of the intellectual Left pretty much always do: read, write, talk, listen, then read and write some more. Nor would accusations from the right have garnered much publicity in the mainstream media or troubled that vast majority of Americans whose views, according to the authors of WDSSGW, are not being adequately represented in our schools or on our college campuses. Indeed, in 1983 (during the Reagan administration) for example, when the U.S. Department of Education published A Nation at Risk, educators discussed its concerns and recommendations, but few people worried very much about the rhetoric used to express its views:

Our Nation is at risk.... The educational foundations of our society are presently being eroded by a rising tide of mediocrity that threatens our very future as a Nation and a people.... If an unfriendly foreign power had attempted to impose on America the mediocre educational 
performance that exists today, we might well have viewed it as an act of war. As it stands, we have allowed this to happen to ourselves.... We have, in effect, been committing an act of unthinking, unilateral educational disarmament. (National Commission on Excellence in Education 1983, http://www.ed.gov/pubs/NatAtRisk/risk.html) But such inflammatory nationalistic language took on new meaning after the attacks on September 11, 2001, a date that the authors of Where Did Social Studies Go Wrong? invoke repeatedly throughout the book. In the current atmosphere of fear and mistrust of those who disagree with American policies, cultural relativism is characterized not just as anti-rigor but as anti-patriotic (Rochester 2003, 25, 40) as well; those who espouse such ideas are not just misguided, but "a threat to liberty"(Leming and Ellington 2003, vi). Suddenly, being "too entrenched in their university posts and their command positions in state education departments" (my italics) takes on ominous overtones. This militaristic imagery, reminiscent of the language used in $\underline{A}$ Nation at

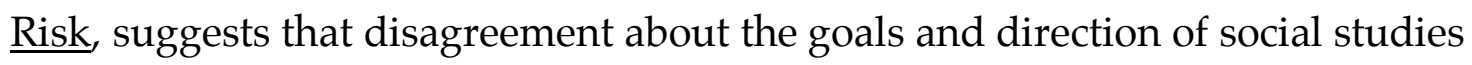
education constitutes a war between right and wrong. Thus, teachers' unions that oppose No Child Left Behind are not merely opponents, they are "terrorists" (according to Rod Paige, George W. Bush's former Secretary of Education). And an accusation like "The keys to Rome are being turned over to the Goths and the Huns" (Finn 2003, V) is more than just a poetic turn of phrase: it implies a battle between civilization (the Right) and the barbarians (the Left), with the Left's treasonous ideas posing a danger to the very fabric of our society. As our President told the world soon after 9/11, you're either with us or you're against us.

It's not just the ideas of Left-leaning social studies educators that threaten civilized society. What makes us even more dangerous is that we're activists, 
ideologues who use the university classroom, which is supposed to be objective and value-neutral, to promote the social change reflected in our own radical agendas. Somehow, classrooms are supposed to introduce objective facts and information without influencing students to take any kind of action: apparently the Neocons do not acknowledge the poststructuralist notion (Cherryholmes 1988) that words and actions are interrelated. Like so many of the labels ascribed to educators in WDSSDW, "activist" is a term that the Neocons apply to more than just the academy. It's also our President's favorite derogatory label for liberal judges, who-unlike conservative judges who, naturally, put aside their biases to ensure objectivity-pursue an ideological agenda through their rulings in the courtroom. The postmodern notion that objectivity is unattainable, that everyone-liberal, conservative, vegetarian, whateversees the world through a lens colored by one's experiences, perspectives, and biases, is apparently inconceivable to the Neocons.

As absurd as the name-calling in WDSSGW (and sprinkled throughout all Neoconservative talk and writing) might seem to scholars who daily ponder the intricacies of such concepts as objectivity, ideology, relativism, and even patriotism, the accumulation of accusations against the academy is having its desired effect. Right now, as I write this, at least seven state legislatures are considering legislation aimed at neutralizing what the Right argues is rampant liberal bias on college campuses (Chu 2005). The ivory tower is under siege.

\section{The Right Frames the Conversation}

How is it possible that just a few labels could so profoundly affect perceptions and actions of legislators and ordinary citizens? According to Gee (1996, 1999), the way we use language not only represents perspectives, but creates them as well; the words 
used to describe an issue or express a particular idea help to mold the way we view that issue or idea. Lakoff (2004) refers to this process as "framing." Frames, Lakoff explains, are mental structures that shape the way we see our world. "All words are defined relative to conceptual frames. When you hear a word, its frame (or collection of frames) is activated in your brain (Lakoff 2004, xv). Thus, for example, Lakoff argues that the term "tax relief" carries a powerful message:

When the word tax is added to relief, the result is a metaphor: Taxation is an affliction. And the person who takes it away is a hero, and anyone who tries to stop him is a bad guy. This is a frame. It is made up of ideas, like affliction and hero. The language that evokes the frame comes out of the White House, and it goes into press releases, goes to every radio station, every TV station, every newspaper. And soon the New York Times is using tax relief. And it is not only on Fox; it is on CNN, it is on NBC, it is on every station because it is "the president's tax-relief plan." And soon the Democrats are using tax relief-and shooting themselves in the foot. (Lakoff 2004, 4)

The repeated use of the phrase "tax relief" puts Democrats in a difficult position. While they may have excellent reasons for opposing tax cuts proposed by the Bush administration, the moment they oppose "tax relief," they are perceived as being against providing relief for the afflicted. As a direct result of the language in use, they have been identified and cast into a role that they hadn't intended. As Luke (1996, p. 13) writes, "Texts position and construct individuals, making available various meanings, ideas, and versions of the world." Giving the name "No Child Left Behind" to the legislation that renewed the 1965 Elementary and Secondary Education Act positions those opposed to the law as being against children. The Right's response to 
opponents of "No Child Left Behind" — who, in most cases, believe that NCLB leaves many children behind (see, for example, Meier and Wood 2004) — is "What? You want to leave some children behind?" and many citizens (and legislators too) unfamiliar with the nuances of this law misconstrue its opponents' resistance. The Neocons have the same response to objections raised about other elements of what Bracey (2005) calls the "Bush administration Orwellian Double Speak program." "Clear Skies," "Clean Waters," and "Healthy Forests" are Bush "environmental" plans which, too many Americans do not seem to realize, will bring us the exact opposite of the images their names invoke. In essence, as Foucault (1977) argues, words and information presented to us define what we see as the "truth" — even when evidence indicates the oppositeabout a given set of ideas.

Now let's look at the frames that Where Did Social Studies Go Wrong? activates for its readers. The authors are "a plucky band of social studies 'contrarians,'" "brave souls... [who] yearned to redeem social studies.... Would they be whistling into a gale? Indeed. Should they nonetheless be encouraged to try? Absolutely" (Finn 2003, V). Unsuspecting readers might assume that the authors, like the spirited rebels of 1776, are in the minority against the "powerful" "forces arrayed on the other side" (Finn 2003, II; note again the militaristic imagery)—plucky little Davids with God on their side fighting the university-supported Goliaths. The images Finn evokes are those of the courageous underdog taking on a brutal tyrant; and whether we're talking about the American Revolution or Star Wars or Lord of the Rings, all the world roots for the underdog and knows he's in the right. They are the patriots, we are the threat to liberty. Included in our unified juggernaut are not only university educators but school systems, professional organizations, textbook companies, and even accrediting bodies like the National Council for the Accreditation of Teacher Education (NCATE) (Burack 
2003, Ellington and Eaton 2003)—all arrayed against the freedom-fighting minority. And all the labels discussed in the previous section that WDSSGW authors ascribe to social studies educators serve to reinforce this frame.

This framing is a common Neocon tactic: characterize the Right as the outsiders, the patriotic minority valiantly battling the oppressive "powerful confluence of institutional forces" (Burack 2003, 47) for truth, objectivity, and the moral high ground. But the frame is pure fiction. In the first place, the authors of Where Did Social Studies Go Wrong? are hardly the underdogs in this arena. They are well endowed by the Fordham Foundation, and at least two of them, Finn and Ravitch, have been part of the educational establishment for more than two decades (both served in the Department of Education during the Reagan/Bush Sr. years). Secondly, social studies educators have never been united in the way the authors say we are. For decades, the members of CUFA and NCSS have argued among themselves, sometimes very acrimoniously, over the purposes, goals, and direction of social studies education. Social studies educators can't even agree on a definition for the term "social studies." Moreover, as long as I have been in education, the Left has had to struggle against the intransigence, conservatism, and massive bureaucracy of state departments of education. If there's a Left-wing social studies conspiracy, I have yet to detect it.

The genius of this anti-freedom-conspiracy strategy is that it positions the Left with no way to respond except to move over to the right. One of the most successful examples of this tactic has been to accuse the media of conspiring to present the news with a liberal bias. In order to refute the accusations, what can newspapers and television do except to avoid reporting stories that might be construed as anti-Right? The news media's response has been to move ever more to the Right, claiming, "We're 
not liberal! Just look at how conservative we are! And here are the news stories to prove it..."

In education, many of the entities that the Right positions as touchy-feely and anti-rigor have tried to dispel such accusations in much the same way. School districts and state departments of education seem to be competing with each other to prove how tough they can be, in some cases developing accountability policies even more stringent than those instituted by the Feds. If too many students succeed on a high school exit exam, the test is automatically thought to be too easy: the district administration, in order to demonstrate its commitment to high standards, is compelled to raise the bar and make the test more difficult (somehow, it is inconceivable that student success could be attributed simply to skilled teachers and diligent students). On a national level, NCATE, the body that accredits many teaching credentialing institutions nationwide, has responded to accusations of anti-rigor and complicity with universities' liberal faculty by ramping up its requirements for accreditation. Earning NCATE accreditation requires university faculty to devote thousands of hours more than ever before to generating, aggregating, and analyzing enormous quantities of "objective" data (whose validity must be established by demonstrating the inter-rater reliability of the accountability measures in place), that, supposedly, will demonstrate the attainment of their programs' high standards. Whether this intensification of faculty workload results in stronger teaching programs is highly debatable, but one thing is certain: it saps faculty of precious time, energy, and morale that could be devoted to teaching or research-or perhaps to battling the accountability juggernaut that threatens every educational institution in the country.

The Right's framing of educators as too lenient has resulted in everyone ramping up top-down accountability measures. But the irony illuminated by diatribes like 
Where Did Social Studies Go Wrong? is that, no matter how much NCATE tries to prove the rigor of its procedures, and no matter how tough and unyielding county and state departments of education show their assessment systems can be, the Right will still lump them together with the liberal purists and progressives at the opposite end of the political spectrum. It seems that only when these entities completely and openly embrace the Neocon agenda will the Neocons endorse them.

Clearly, the labels and accusations peppered throughout Where Did Social

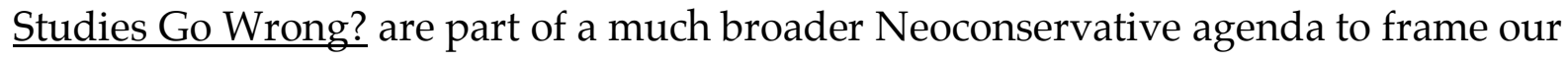
overall vision of education and move us farther to the right. I shudder to imagine the ultra-nationalistic test-driven curricula that could result from WDSSGW's framing of progressive, global, multicultural, and environmental social studies education-especially if textbook publishers, professional organizations, and offices of education respond as so many entities have to similar accusations from the Right. As these constituencies outdo one another to demonstrate their patriotic zeal and commitment to rigid teacher-directed instruction, the modest gains that we've achieved over the past thirty years could quickly disappear.

\section{Reclaiming and Reframing the Conversation}

The scenario described above is frightening, but it is not inevitable. We need to become more adept at recognizing when the Right is manipulating the conversation and seek ways to neutralize and then counteract those frames. As Lakoff $(2004,33)$ writes, "If you keep their language and their framing and just argue against it, you lose because you are reinforcing their frame.... You need to frame the truths effectively from your perspective." Unfortunately, this is not an easy task. It is all too easy to fall 
prey to the frames that the Right has already successfully established in the minds of most Americans. Here are a few suggestions for reclaiming the conversation:

- Take back our language. We need, as Goodman (2001) suggests, to reclaim the language whose meaning has been taken from us by the Neocons' framingwords such as patriotism that belong to all of us but that the Right has claimed for its own, and words like activism, progressivism, and liberalism, once thought to represent cornerstones of democratic participation and empowerment, which we've allowed the Right to twist into something evil and anti-American. It is not enough simply to argue that we, too, are patriots, or that we're not activists because the Right currently "owns" those words. In most people's minds, for example, the concept of patriotism is inextricably connected to the Bush Doctrine's militaristic agenda and the Patriot Act's constriction of civil liberties. Nobody would believe that I'm as patriotic as the WDSSGW authors are because, given their jingoistic definition of patriotism, I'm not. I would be much better off challenging their notion of patriotism, seeking to establish a whole new way of looking at it-perhaps considering how love of country must involve protecting its environment from profit-seeking energy companies or safeguarding its citizens by protecting the Bill of Rights and seeking ways to understand those different from us.

- $\quad$ Stand up for what we believe. Those whom the Right accuses of being progressive or anti-patriotic must stop capitulating to demands that they accede to the Neocon agenda. Once we have begun to reclaim the above words and embraced them as values essential to all Americans, then we can begin to redirect the discussion about the goals of social studies education. Why, after all, should patriotism, as the authors of WDSSGW define it, be the centerpiece of social 
studies education? We should be focusing on citizenship, community, participation, and, yes, activism: not in the terms of condemnation used in WDSSGW, but to affirm the importance of active citizen participation in a democratic society. Instead of denying that we're activists, we should be saying, "You're absolutely right we're activists! We're proud of it, and here's why...." When mainstream Americans see activism as vital to the democratic process, when they understand that progressivism is a means for fostering student engagement and participation-and also sophisticated knowledge construction and acquisition—-then perhaps individuals, organizations, and institutions will be able to stand up for their beliefs and withstand the Neocons' relentless pressure to move ever more to the right.

- Join together. We need to turn the Neocons' imagined Left-wing power block into a reality. The fragmentation within and among the many entities they lump together-universities, schools, departments of education, professional organizations, and accrediting bodies like NCATE—has made it too easy for the Right to take control of the agenda. We need to acknowledge the threat to intellectual freedom and meaningful social studies education that the Right poses for all of us, put aside the acrimony that has historically divided us, and together develop a range of strategies for counteracting that threat.

The Right has been very successful in developing strategies for joining forces and shaping the way people view political and social issues. Ross and Marker (2005) point out that there are currently more than 100 conservative think tanks (among them the Fordham Foundation, which published WDSSGW), whose purpose is to influence people's perceptions and public policy through research, philanthropy, public relations, and networking (despite the Neocons' claims of 
objectivity). The Left needs to catch up. Perhaps left-leaning policy institutes could help find the common ground that we need to counteract the Right's influence on our language and perceptions. Rockridge Institute (2005), whose goal is to "reframe the public debate to make a progressive moral vision more persuasive and resonant," is one such think tank, but we need many more.

- Communicate outside the academy. Finally, the key to reframing the conversation is to speak and write in ways that will encourage people outside the academy to listen to us and hear our perspectives. The Right already knows how to do this. Neocons have become masters of persuasion, and one of the ways they have achieved this end is to express their ideas in a simple, conversational style that clearly communicates the message that they intend to convey. Every month I receive in the mail several Neoconservative newsletters (my Republican father-in-law, in an apparent effort to help me see the light, put my name on several mailing lists). The ideas in these newsletters are presented succinctly and compellingly, in a way that just about anybody could easily understand. The articles are short enough to complete over a bowl of cereal; no references to relevant scholarship clutter the text; and little jargon complicates the message. Where Did Social Studies Go Wrong? also makes use of this strategy. The authors of the chapter entries might argue that most of their pieces contain sophisticated lines of reasoning and numerous citations; but my guess is that few readers—or sound bites or press releases—of this book will look beyond the short, plain-speaking Preface and Introduction.

In contrast to the Neocons' simple rhetorical style, the Left, for the most part, provides its audience with scholarly arguments that are beautifully articulated-but, unfortunately, few but other scholars and like-minded liberals 
bother to read them. Even teachers-about whose professional lives we are writing - find little interest or value in most educational theory, research, and school reform literature. We need to widen our audience-to write books that can be found in mainstream bookstores and public libraries, books that people outside the academy will actually read.

In fact, this is gradually beginning to happen. Of course, media personalities like Al Franken (2003) and Michael Moore(2001) have been publishing popular books for a few years; but now we're also beginning to see books by academics in people's shopping bags. After presenting his theories about framing in a scholarly work (Lakoff 2002), Lakoff wrote Don't Think of An Elephant (2004) in plain English, with no reference list, no reviews of relevant research, and no scholarly jargon. Only since the publication of the latter book have his theories gained the attention of the mainstream. Similarly, Many Children Left Behind (Meier and Wood 2004) includes powerful essays written by renowned scholars, but in easily accessible prose. This article, which I intentionally wrote in a conversational style, is meant to demonstrate that it's possible to be succinct (although not succinct enough to finish over breakfast) while still providing a cogent argument. The Left needs to produce more such arguments, using all available media-essays, fiction, poetry, television, movies-to communicate with citizens to help reframe the conversation about social studies education.

Where Did Social Studies Go Wrong? confronts social studies educators with the question that Foucault (cited in Cherryholmes 1988, p. 36) asked years ago: "How can people gain control of their discourses ... instead of being controlled by them?" As successful as the Neoconservative agenda has been of late, there is still much that we 
can do to counteract the ongoing attacks on educational institutions at all levels and the students these institutions serve. It is time for members of the academy to dedicate ourselves, through communication with people both within and outside the ivory tower, to counteracting the Right's growing influence on the minds and mindsets of the American people. 


\section{References}

Apple, M. W. 1996. Cultural politics and education. New York: Teachers College Press.

Bracey, G. W. 2005. Seven deadly absurdities. ZNet/Education. http://www.zmag.org/content/print article.cfm?itemID=7219\&sectionID=101 Retrieved February 16, 2005.

Burack, J. 2003. The student, the world, and the global education ideology. In Where did social studies go wrong?, eds. J. Leming, L. Ellington, \& K. Porter. Washington, DC: Thomas B. Fordham Foundation.

Cherryholmes, C.H. 1988. Power and criticism: Poststructural investigations in education. New York: Teachers College Press.

Chu, J. 2005. Fighting words 101. Time 165(11): 38-39.

Ellington, L. and Eaton, J.S. 2003. Multiculturalism and social studies. In Where did social studies go wrong?, eds. J. Leming, L. Ellington, \& K. Porter. Washington, DC: Thomas B. Fordham Foundation.

Finn, Jr., C.E. 2004. Foreword. In Where did social studies go wrong? eds. J. Leming, L. Ellington, \& K. Porter. Washington, DC: Thomas B. Fordham Foundation. Foucault. M. 1977. Discipline and punish: Birth of the prison. London: Allen Lane. Franken, A. 2003. Lies and the lying liars who tell them: A fair and balanced look at the right. New York: Dutton.

Frazee, B., \& Ayers, S. 2003. Garbage in, garbage out: Expanding environments, constructivism, and content knowledge in social studies. In Where did social studies go wrong?, eds. J. Leming, L. Ellington, \& K. Porter. Washington, DC: Thomas B. Fordham Foundation. 
Gee, J.P. 1996. Social linguistics and literacies: Ideology in discourses, $2^{\text {nd }}$ ed. Bristol, PA: Falmer Press.

Gee, J.P. 1999. An introduction to discourse analysis: Theory and method. London: Routledge.

Goodman, J. 2001.

Harding. S., ed. 1987. Feminism and methodology. Bloomington, IN: Indiana University Press.

Kohn, A. 2004 NCLB and the effort to privatize public education. In Many children left behind: How the No Child Left Behind act is damaging our children and our schools, eds. D. Meier \& G. Wood. Boston: Beacon Press.

Kornfeld, J., \& Goodman, J. 1998. Melting the glaze: Exploring student responses to liberatory social studies. Theory Into Practice 37(4): 306-313.

Lakoff, G. 2002. Moral politics: How liberals and conservatives think, $2^{\text {nd }}$ ed. Chicago: University of Chicago Press.

Lakoff, G. 2004. Don't think of an elephant!: Know your values and frame the debate. White River Junction, VT: Chelsea Green.

Leming, J. 2003. Ignorant activists: Social change, "higher order thinking," and the failure of social studies. In Where did social studies go wrong?, eds. J. Leming, L. Ellington, \& K. Porter. Washington, DC: Thomas B. Fordham Foundation.

Leming, J., \& Ellington, L. 2003. Introduction. In Where did social studies go wrong? eds. J. Leming, L. Ellington, \& K. Porter. Washington, DC: Thomas B. Fordham Foundation.

Leming, J., Ellington, L., \& Porter, K., eds. Where did social studies go wrong? Washington, DC: Thomas B. Fordham Foundation.

Luke, A. 1996. Text and discourse in education: An introduction to critical discourse 
analysis. Review of Educational Research 21: 3-48.

Meier, D., \& Wood, G., eds. Many children left behind: How the No Child Left Behind act is damaging our children and our schools. Boston: Beacon Press.

Moore, M. 2001. Stupid white men ...and other sorry excuses for the state of the nation! New York: HarperCollins.

National Commission on Excellence in Education. 1983. A nation at risk: The imperative for educational reform. A Report to the Nation and the Secretary of Education United States Department of Education. http://www.ed.gov/pubs/NatAtRisk/risk.html Retrieved March 25, 2005.

Rochester, J.M. 2003. The training of idiots: Civics education in America's schools. In Where did social studies go wrong? eds. J. Leming, L. Ellington, \& K. Porter. Washington, DC: Thomas B. Fordham Foundation.

Rockridge institute. 2005. http://www.rockridgeinstitute.org Retrieved March 25, 2005.

Ross, E.W., \& Marker. P.M. 2005. (If social studies is wrong) I don't want to be right. Theory and Research in Social Education 33(1): 142-151.

Schug, M.C. 2003. Teacher-centered instruction: The Rodney Dangerfield of social studies. In Where did social studies go wrong?, eds. J. Leming, L. Ellington, \& K. Porter. Washington, DC: Thomas B. Fordham Foundation. 